\title{
CORRIGENDUM
}

\section{Interferon regulatory factor-1 polymorphisms are associated with the control of Plasmodium falciparum infection}

VD Mangano, G Luoni, KA Rockett, BS Sirima, A Konaté, J Forton, TG Clark, G Bancone, E Sadighi Akha, DP Kwiatkowski and D Modiano

Genes and Immunity (2008) 9, 482; doi:10.1038/gene.2008.47

Correction to: Genes and Immunity (2008) 9, 122-129;

doi:10.1038/sj.gene. 6364456

Since publication of this paper, the authors have noticed that E Sadighi Akha's name was published incorrectly.

The correct name is shown above.

The authors would like to apologize for this error. 